\title{
A Single Amino Acid Residue at Transmembrane Domain 4 of the $\alpha$ Subunit Influences Carisoprodol Direct Gating Efficacy at $\mathrm{GABA}_{\mathrm{A}}$ Receptors
}

\author{
Manoj Kumar, ${ }^{1}$ Manish Kumar, John M. Freund, and Glenn H. Dillon \\ Department of Physiology and Pharmacology, Center for Neuroscience, Robert C. Byrd Health Sciences Center, West Virginia \\ University, Morgantown, West Virginia (Mo.K., Mi.K., J.M.F., G.H.D.); and Center for Neuroscience Discovery, Institute for \\ Healthy Aging, University of North Texas Health Science Center, Fort Worth, Texas (Mi.K., G.H.D.)
}

Received April 11, 2017; accepted June 14, 2017

\begin{abstract}
The muscle relaxant carisoprodol has recently been controlled at the federal level as a Schedule IV drug due to its high abuse potential and consequences of misuse, such as withdrawal syndrome, delusions, seizures, and even death. Recent work has shown that carisoprodol can directly gate and allosterically modulate the type $A$ GABA $\left(\mathrm{GABA}_{A}\right)$ receptor. These actions are subunit-dependent; compared with other $\mathrm{GABA}_{\mathrm{A}}$ receptors, carisoprodol has nominal direct gating effects in $\alpha 3 \beta 2 \gamma 2$ receptors. Here, using site-directed mutagenesis and whole-cell patch-clamp electrophysiology in transiently transfected human embryonic kidney 293 cells, we examined the role of $\mathrm{GABA}_{\mathrm{A}}$ receptor $\alpha$ subunit transmembrane domain 4 (TM4) amino acids in direct gating and allosteric modulatory actions of carisoprodol. Mutation of $\alpha 3$ valine at position 440 to leucine (present in the
\end{abstract}

equivalent position in the $\alpha 1$ subunit) significantly increased the direct gating effects of carisoprodol without affecting its allosteric modulatory effects. The corresponding reverse mutation, $\alpha 1(\mathrm{~L} 415 \mathrm{~V})$, decreased carisoprodol direct gating potency and efficacy. Analysis of a series of amino acid mutations at the 415 position demonstrated that amino acid volume correlated positively with carisoprodol efficacy, whereas polarity inversely correlated with carisoprodol efficacy. We conclude that $\alpha 1(415)$ of TM4 is involved in the direct gating, but not allosteric modulatory, actions of carisoprodol. In addition, the orientation of alkyl or hydroxyl groups at this position influences direct gating effects. These findings support the likelihood that the direct gating and allosteric modulatory effects of carisoprodol are mediated via distinct binding sites.

\section{Introduction}

The centrally acting muscle relaxant carisoprodol $(\mathrm{N}$ isopropyl meprobamate) is frequently prescribed for skeletal muscle pain (Luo et al., 2004; Toth and Urtis, 2004). In recent years, misuse and abuse of carisoprodol has become a significant problem. Carisoprodol abuse causes psychomotor impairment and severe withdrawal that may predispose to seizures and death (Bramness et al., 2004; Fass, 2010; Zacny and Gutierrez, 2011; Zacny et al., 2011; Reeves et al., 2012). Tolerance to carisoprodol develops relatively quickly, facilitating the problems associated with withdrawal (Reeves and Burke, 2010; Gatch et al., 2012). Indeed, considering its alarming abuse rate, carisoprodol was controlled as a Schedule IV substance at the federal level effective January 2012 (Reeves et al., 2012).

Until recently, it was widely accepted that the sedative and muscle-relaxing effects of carisoprodol were predominantly

This research was supported by the National Institutes of Health National Institute on Drug Abuse [Grant R01-DA022370 (to G.H.D.)] and the National Institutes of Health National Institute of General Medical Sciences [Grant U54-GM104942].

${ }^{1}$ Current affiliation: Department of Otolaryngology, University of Pittsburgh, Pittsburgh, Pennsylvania.

https://doi.org/10.1124/jpet.117.242156. due to its primary metabolite, meprobamate (Bramness et al., 2004). More recent work has shown that carisoprodol itself allosterically modulates, directly activates and blocks type A GABA $\left(\mathrm{GABA}_{\mathrm{A}}\right)$ receptors in a concentration-dependent manner (Gonzalez et al., 2009a,b). In vivo studies also support the fact that carisoprodol itself has significant central nervous system effects due to interaction with $\mathrm{GABA}_{\mathrm{A}}$ receptors.

$\mathrm{GABA}_{\mathrm{A}}$ receptors are member of the cys-loop family of ligandgated ion channels; they are heteropentameric $\mathrm{Cl}^{-}$channels and play a critical role in mediating fast inhibition in the brain (Corringer et al., 2012; Sigel and Steinmann, 2012). Multiple $\mathrm{GABA}_{\mathrm{A}}$ receptor subunits and corresponding isoforms have been identified, including $\alpha$ (1-6), $\beta(1-3), \gamma(1-3), \rho, \delta, \varepsilon$, and $\theta$ (Olsen and Sieghart, 2008). Each subunit is composed of a large extracellular $\mathrm{N}$ terminus, four transmembrane (TM) helices (TM1-TM4), an extracellular TM2-TM3 loop, a large TM3-TM4 intracellular loop, and an extracellular C terminus (Cockcroft et al., 1995). The TM2 domains form the pore of the channel (Xu and Akabas, 1996; Miyazawa et al., 2003) (Fig. 1). In addition to the GABA binding site, $\mathrm{GABA}_{\mathrm{A}}$ receptors have binding sites for several clinically important drugs, including anxiolytics, sedative hypnotics, muscle relaxants, and anesthetics. In $\alpha 1 \beta 2 \gamma 2$ receptors, the GABA binding site is located at the interface of the $\alpha 1$ and $\beta 2$ subunits, and benzodiazepines 
bind at the interface of the $\alpha 1$ and $\gamma 2$ subunits in the extracellular region (Newell and Czajkowski, 2003; Sigel and Steinmann, 2012) (Fig. 1). Barbiturate and general anesthetic (propofol, etomidate) binding sites are believed to be positioned in the water-accessible region located between the TM helices of the receptor (Siegwart et al., 2002; Bali and Akabas, 2004; Zeller et al., 2007a,b). Carisoprodol actions are not mediated via reported sites of action for benzodiazepines or barbiturates (Gonzalez et al., 2009b). Although the general anesthetics propofol and etomidate allosterically modulate and directly gate $\mathrm{GABA}_{\mathrm{A}}$ receptors through a single site of action (Siegwart et al., 2002; Stewart et al., 2013), distinct $\mathrm{GABA}_{\mathrm{A}}$ receptor sites confer these properties to neurosteroids (Hosie et al., 2006). Work to date suggests that carisoprodol may mediate its allosteric modulatory and direct gating effects via distinct sites of action (Gonzalez et al., 2009b).

Our recent studies with carisoprodol on $\mathrm{GABA}_{\mathrm{A}}$ receptors have shown that the allosteric modulatory and direct gating properties of carisoprodol are subunit-dependent (Kumar et al., 2015). Allosteric modulatory actions of carisoprodol are most efficacious at receptors incorporating the $\alpha 1$ subunit, whereas $\alpha 3$-expressing receptors show minimal direct gating effects. Characteristics of carisoprodol effects are consistent with it interacting at the TM domains (Hosie et al., 2006). Aligned amino acid sequences of the human $\alpha$-subunit isoforms ( $\alpha 1-6)$ revealed that TM1, TM2, and TM3 are fully conserved in all $\alpha$-subunit isoforms. The TM4 region of $\alpha$-subunit isoforms is also largely conserved; however, I419, I423, and V440 residues of $\alpha 3$ differ compared with all other $\alpha$-subunit isoforms (Fig. 1C) (Barnard et al., 1998; Bergmann et al., 2013). We thus explored the extent to which these residues may contribute to the ability of carisoprodol to directly gate and allosterically modulate $\mathrm{GABA}_{\mathrm{A}}$ receptors. We have identified L415 at TM4 of the $\alpha 1$ subunit (equivalent to V440 in the $\alpha 3$ subunit) as being critically involved in the direct gating actions of carisoprodol without affecting its allosteric modulatory effects.

\section{Materials and Methods}

Plasmids and Site-Directed Mutagenesis. Human cDNA plasmids encoding $\alpha 1, \alpha 3, \beta 2$, and $\gamma 2 \mathrm{GABA}_{\mathrm{A}}$ receptor subunits were used in this study. Individual and combined mutations in $\alpha 1$ and $\alpha 3$ cDNA plasmids were created using Stratagene's Quik Change II site-directed mutagenesis kit (Agilent Technologies, La Jolla, CA) and were sequenced at the West Virginia University Genomics Core Facility (Morgantown, WV) to confirm mutations.

Chemicals and Solutions. Carisoprodol, meprobamate, pentobarbital, salts, and buffers were purchased from Sigma-Aldrich (St. Louis, MO), and GABA was obtained from Acros Organics (Morris, NJ). Pentobarbital and GABA stock solutions $(500 \mathrm{mM})$ were prepared in deionized water. Carisoprodol stock solution (1 M) was made in dimethylsulfoxide. All stock solutions were stored at $-20^{\circ} \mathrm{C}$. On the day of the experiment, fresh working drug concentrations were prepared from stock solution by dissolving in physiologic buffer solution (below).

Cell Culture and Transfection. Human embryonic kidney 293 (HEK293) cells were transfected with human cDNA encoding the desired $\mathrm{GABA}_{\mathrm{A}}$ receptor subunits. To obtain $\alpha \mathrm{x} \beta 2 \gamma 2 \mathrm{GABA}_{\mathrm{A}}$ receptors, HEK293 cells were transfected with the human GABA $_{A} \alpha 1 / 3$ mutant or wild-type, human $\beta 2$, and human $\gamma 2 \mathrm{~s}$ (short isoform) subunit cDNA in a 1:1:5 ratio $(0.3 \mu \mathrm{g} / 0.3 \mu \mathrm{g} / 1.5 \mu \mathrm{g})$ using PolyJet DNA in vitro transfection reagent (SignaGen Laboratories, Rockville, MD) and were used for recording 24-48 hours later. The $\gamma 2$ s subunit will be referred to as $\gamma 2$ from this point forward. The human $\mathrm{GABA}_{\mathrm{A}} \alpha 1$-subunit cDNA was generously provided by Neil Harrison (Columbia University Medical Center, New York, NY). Cells were plated on glass coverslips coated with poly(L-lysine) in 35-mm culture dishes and were incubated and maintained at $37^{\circ} \mathrm{C}$ in a humidified incubator with an atmosphere of $5 \% \mathrm{CO}_{2}$.

Whole-Cell Patch-Clamp Electrophysiology. All experiments were conducted at room temperature $\left(22-25^{\circ} \mathrm{C}\right)$ with the membrane potential clamped at $-60 \mathrm{mV}$. Patch pipettes of borosilicate glass (1B150F; World Precision Instruments Inc., Sarasota, FL) were pulled (Flaming/Brown, P-87/PC; Sutter Instrument Company, Novato, CA) to a tip resistance of 4-6 M $\Omega$. Patch pipettes were filled with a solution consisting of $140 \mathrm{mM} \mathrm{CsCl}, 10 \mathrm{mM}$ EGTA-Na ${ }^{+}, 10 \mathrm{mM}$ HEPES-Na ${ }^{+}$, and $4 \mathrm{mM} \mathrm{Mg}{ }^{2+}$-ATP, $\mathrm{pH}$ 7.2. Coverslips containing cultured cells were placed in the recording chamber on the stage of an inverted light microscope and superfused continuously with an external solution

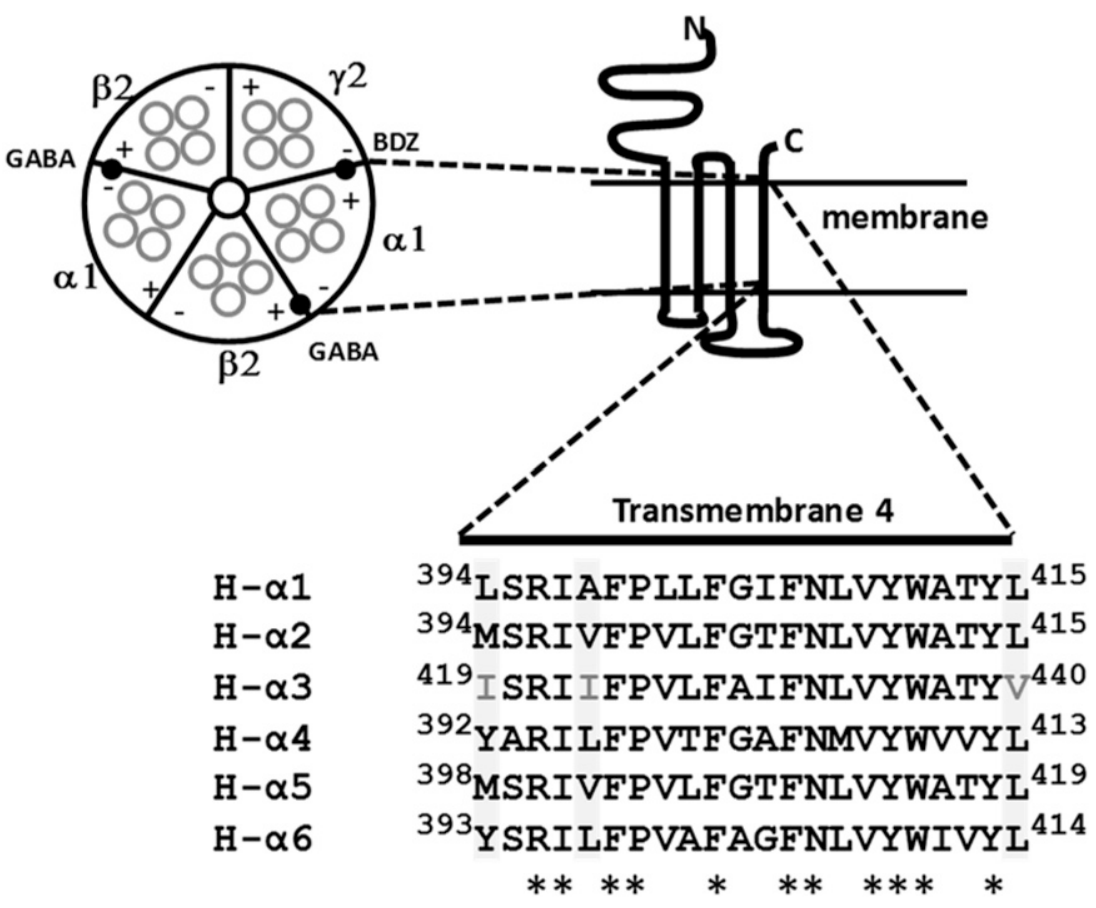

Fig. 1. $\mathrm{GABA}_{\mathrm{A}}$ receptor structure and alignment of the TM4 amino acid residue of $\alpha(1-6)$ GABA $_{\mathrm{A}}$ receptor subunits. (Top Left) View from the membrane of a GABA $_{A}$ receptor expressing $\alpha 1, \beta 2$, and $\gamma 2$ subunits and denoting GABA and BDZ binding sites. (Top Right) Lateral view of a $\mathrm{GABA}_{\mathrm{A}}$ receptor subunit, illustrating four transmembrane domains, the extracellular $\mathrm{N}$ terminus, the $\mathrm{C}$ terminus, and the intracellular loop. (Bottom) The aligned amino acid sequence of the TM4 region of human $\alpha$-subunit ( $\alpha 1-6)$ isoforms showing conserved (asterisk) and nonidentical (shaded in gray) amino acids. BDZ, benzodiazepine. 
TABLE 1

Summary effects of $\mathrm{GABA}_{\mathrm{A}}$ receptor $\alpha 3$ to $\alpha 1 \mathrm{TM} 4$ amino acid mutations on $\mathrm{GABA}_{\mathrm{EC}_{50}}$ and carisoprodol direct and allosteric actions

Each data point represents the mean \pm S.E. of $n$ cells. Carisoprodol direct gating activation at $3 \mathrm{mM}$ is normalized to peak GABA current, and carisoprodol allosteric modulatory effects are normalized to $\mathrm{GABA}_{\mathrm{EC}} \mathrm{C}_{20}$ currents.

\begin{tabular}{|c|c|c|c|c|c|c|}
\hline \multirow{2}{*}{$\mathrm{GABA}_{\mathrm{A}}$ Receptor Configuration } & \multicolumn{2}{|c|}{$\mathrm{GABA}^{\mathrm{E} \mathrm{E}_{50}}$} & \multicolumn{2}{|c|}{ CSP Gating } & \multicolumn{2}{|c|}{ CSP Modulation } \\
\hline & $\mathrm{EC}_{50}$ & Cells & $3 \mathrm{mM}$ CSP & Cells & $300 \mu \mathrm{M} \mathrm{CSP}$ & Cells \\
\hline & $\mu \mathrm{M}$ & $n$ & $\%$ & $n$ & $\%$ & $n$ \\
\hline$\alpha 3 \mathrm{WT}$ & $34.8 \pm 2.1$ & 6 & $08.5 \pm 1.1$ & 11 & $235 \pm 35$ & 6 \\
\hline$\alpha 3(\mathrm{~V} 440 \mathrm{~L})$ & $7.5 \pm 0.9 *$ & 7 & $37.6 \pm 3.5^{*}$ & 9 & $301 \pm 14$ & 5 \\
\hline$\alpha 3(\mathrm{I} 419 \mathrm{~L} / \mathrm{I} 423 \mathrm{~A})$ & $18.1 \pm 2.2^{* *}$ & 9 & $40.8 \pm 2.4^{*}$ & 8 & $252 \pm 14$ & 4 \\
\hline$\alpha 3(\mathrm{I} 419 \mathrm{~L} / \mathrm{I} 423 \mathrm{~A} / \mathrm{V} 440 \mathrm{~L})$ & $15.8 \pm 5.0^{* *}$ & 6 & $35.9 \pm 3.9 *$ & 10 & $156 \pm 22$ & 6 \\
\hline
\end{tabular}

CSP, carisoprodol; WT, wild type.

$* P<0.01 ;{ }^{* *} P<0.05$ (relative to WT $\alpha 3 \beta 2 \gamma 2 \mathrm{GABA}_{\mathrm{A}}$ receptors)

consisting of $125 \mathrm{mM} \mathrm{NaCl}, 20 \mathrm{mM}$ HEPES, $3 \mathrm{mM} \mathrm{CaCl}_{2}, 5.5 \mathrm{mM} \mathrm{KCl}$, $0.8 \mathrm{mM} \mathrm{MgCl} 2$, and $10 \mathrm{mM}$ glucose, $\mathrm{pH}$ 7.4. Agonist-induced $\mathrm{Cl}^{-}$ currents were obtained with an Axopatch 200B amplifier with a rate of 50 samples per second (Molecular Devices, Sunnyvale, CA) equipped with a CV-203BU head stage. Currents were low-pass filtered at $5 \mathrm{kHz}$, monitored simultaneously on an oscilloscope and a chart recorder (Gould TA240; Gould Instrument Systems Inc., Cleveland, $\mathrm{OH})$, and stored on a computer using an online data acquisition system (pCLAMP 6.0; Axon Instruments, Sunnyvale, CA) for subsequent off-line analysis.

Experimental Protocol. GABA (with or without carisoprodol) or carisoprodol was prepared in external saline solution from stock solutions and applied to each cell by gravity flow using a Y-shaped tube positioned adjacent to the cell. Recordings were obtained from transfected cells only after establishing that two consecutive GABA $\mathrm{EC}_{20}$-activated currents varied in amplitude by no more than $\pm 10 \%$. For studies investigating direct activation, carisoprodol-mediated currents were normalized to currents elicited by saturating GABA concentrations. Modulatory effects of carisoprodol on GABA-gated currents were assessed using an $\mathrm{EC}_{20}$ gating concentration of GABA as the control (individually determined for each mutant and wild-type receptor studied). This gating concentration was selected to ensure that there was a sufficient range to observe the full allosteric potential of carisoprodol. At the initiation of each recorded cell, it was confirmed that gating concentration was approximately the $\mathrm{EC}_{20}$ (range of $\mathrm{EC}_{15}$ to $\mathrm{EC}_{25}$ accepted for an individual cell). In recordings displaying inhibition followed by a rebound current after termination of carisoprodol or carisoprodol plus GABA application (Gonzalez et al., 2009b), the maximal current amplitude achieved during active ligand application was taken as the peak current (Kumar et al., 2015).

Data Analysis. Concentration-response profiles for the positive modulatory actions of carisoprodol were generated (Origin 9.1; OriginLab

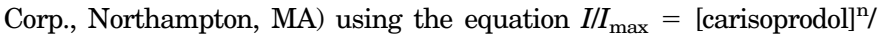

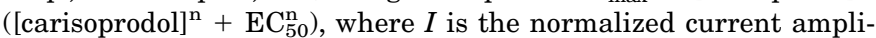
tude at a given concentration of carisoprodol, $I_{\max }$ is the maximum current induced by carisoprodol, $\mathrm{EC}_{50}$ is the half-maximal effective concentration of carisoprodol, and $\mathrm{n}$ is the Hill coefficient. For concentration-response curves illustrating allosteric actions, a correction was applied to subtract direct gating effects. In some cases, the blocking actions of carisoprodol became notable at high concentrations; in these instances, curves were fitted to the data point corresponding to the peak effect, and the curve was extrapolated. All data are presented as means \pm S.E. Statistical significance between the control and test conditions was determined using the $t$ test (paired or unpaired) and one-way analysis of variance. The Tukey-Kramer post hoc test for multiple comparisons was performed as needed. Correlation assessments were performed using linear fit in Origin 9.1 software.

TABLE 2

Influence of GABA $\mathrm{A}_{\mathrm{A}}$ receptor $\alpha 3$ to $\alpha 1$ single and combination TM4 mutations and $\alpha 1$ (L415) amino acid substitutions on $\mathrm{GABA}_{\mathrm{EC}}$ volues and carisoprodol direct gating

Each data point represents the mean \pm S.E. of $n$ cells. Carisoprodol direct gating activation is normalized to saturated GABA current, whereas carisoprodol modulation effect to potentiate GABA-gated current is normalized to GABA EC ${ }_{2}$ current.

\begin{tabular}{|c|c|c|c|c|c|}
\hline \multirow{2}{*}{$\mathrm{GABA}_{\mathrm{A}}$ Receptor Configuration } & \multicolumn{2}{|c|}{ GABA } & \multicolumn{3}{|c|}{ CSP Direct Gating } \\
\hline & $\mathrm{EC}_{50}$ & Cells & Maximum Efficacy & $\mathrm{EC}_{50}$ & Cells \\
\hline & $\mu \mathrm{M}$ & $n$ & $\%$ & $\mu \mathrm{M}$ & $n$ \\
\hline$\alpha 1 \mathrm{WT}$ & $35.5 \pm 0.6$ & 5 & $41.8 \pm 2.4$ & $685 \pm 32$ & 15 \\
\hline$\alpha 1$ (L394I) & $50.8 \pm 4.4$ & 4 & $40.6 \pm 4.6$ & $559 \pm 50$ & 6 \\
\hline$\alpha 1$ (A398I) & $35.2 \pm 4.1$ & 5 & $36.1 \pm 2.9$ & $617 \pm 83$ & 6 \\
\hline$\alpha 1(\mathrm{~L} 415 \mathrm{~V})$ & $89.0 \pm 2.2^{*}$ & 5 & $17.7 \pm 3.1^{*}$ & $826 \pm 24$ & 9 \\
\hline$\alpha 1$ (L394I/A398I) & $27.0 \pm 3.4$ & 3 & $42.0 \pm 5.7$ & $443 \pm 28$ & 9 \\
\hline$\alpha 1(\mathrm{~A} 398 \mathrm{I} / \mathrm{L} 415 \mathrm{~V})$ & $68.4 \pm 4.2^{*}$ & 3 & $22.6 \pm 1.8^{*}$ & $456 \pm 40$ & 5 \\
\hline$\alpha 1$ (L394I/L415V) & $27.5 \pm 3.1$ & 3 & $20.5 \pm 3.2^{*}$ & $864 \pm 21$ & 9 \\
\hline$\alpha 1$ (L394I/A398I/L415V) & $44.1 \pm 2.4$ & 7 & $18.2 \pm 4.5^{*}$ & $380 \pm 20$ & 7 \\
\hline$\alpha 1(\mathrm{~L} 415 \mathrm{C})$ & $39.4 \pm 4.0$ & 4 & $18.0 \pm 1.6^{*}$ & $697 \pm 41$ & 9 \\
\hline$\alpha 1(\mathrm{~L} 415 \mathrm{~W})$ & $47.7 \pm 2.3$ & 3 & $17.8 \pm 4.1^{*}$ & $2056 \pm 122 *$ & 6 \\
\hline$\alpha 1$ (L415G) & $68.0 \pm 4.3^{*}$ & 4 & $09.1 \pm 1.6^{*}$ & $545 \pm 10$ & 5 \\
\hline$\alpha 1(\mathrm{~L} 415 \mathrm{~S})$ & $65.0 \pm 4.2^{*}$ & 7 & $05.5 \pm 1.2^{*}$ & $651 \pm 24$ & 13 \\
\hline$\alpha 1(\mathrm{~L} 415 \mathrm{~T})$ & $41.0 \pm 2.1$ & 4 & $37.1 \pm 4.4$ & $533 \pm 41$ & 9 \\
\hline$\alpha 1$ (L415Y) & $45.0 \pm 3.2$ & 4 & $25.4 \pm 3.8$ & $807 \pm 55$ & 6 \\
\hline$\alpha 1(\mathrm{~L} 415 \mathrm{I})$ & $40.3 \pm 2.2$ & 4 & $31.9 \pm 4.1$ & $450 \pm 30$ & 7 \\
\hline$\alpha 1(\mathrm{~L} 415 \mathrm{R})$ & $43.4 \pm 5.2$ & 4 & $32.6 \pm 4.6$ & $492 \pm 24$ & 4 \\
\hline
\end{tabular}

CSP, carisoprodol; WT, wild type

$* P<0.01$ (relative to wild-type $\alpha 1 \beta 2 \gamma 2 \mathrm{GABA}_{\mathrm{A}}$ receptors). 


\section{Results}

Functional Characterization of $\alpha 3$ and $\alpha 1$ TM4 Mutant GABA $\mathbf{A}_{\mathbf{A}}$ Receptors. For this study, an extensive series of mutations (a single point or two to three residues) in $\alpha 1$ and $\alpha 3$ subunits were evaluated. In all cases, the mutant subunit was expressed with wild-type $\beta 2$ and $\gamma 2$ subunits, and GABA concentration-response profiles were generated to assess overall receptor function and to establish gating concentrations for allosteric studies. GABA $\mathrm{EC}_{50}$ values for wild-type $\alpha 1$ and $\alpha 3$ receptors were both approximately $35 \mu \mathrm{M}$ (Tables 1 and 2 ). In general, shifts in GABA EC $_{50}$ were modest. Mutations in $\alpha 3$ subunits caused a leftward shift of 1.9- to 4.6-fold in the GABA concentration-response curve (Table 1). Similarly, mutations in the $\alpha 1$ subunit had either insignificant or modest effects on GABA EC $_{50}$, with the maximal effect being a 2.5 -fold increase in GABA $\mathrm{EC}_{50}$ relative to wild-type $\alpha 1$ receptors (Table 2 ). Thus, the mutations had minimal effects on fundamental receptor gating.

Mutation of $\alpha 3$ TM4 Amino Acids to Corresponding $\alpha 1$ Amino Acids Increased the Direct Gating Effect of Carisoprodol But Not Allosteric Modulatory Actions. Consistent with our previous report (Kumar et al., 2015), the ability of carisoprodol to directly gate $\alpha 3 \beta 2 \gamma 2$ receptors was significantly less compared with $\mathrm{GABA}_{\mathrm{A}}$ receptors expressing the $\alpha 1$ subunit (Fig. 2B; Tables 1 and 2). To evaluate the direct gating efficacy of carisoprodol, we normalized the carisoprodolgated currents to saturated GABA-gated current amplitudes. Maximal current amplitudes generated by $3 \mathrm{mM}$ carisoprodol were $41.8 \% \pm 2.4 \%$ in $\alpha 1 \beta 2 \gamma 2$ receptors and $8.5 \% \pm 1.1 \%$ in $\alpha 3 \beta 2 \gamma 2$ receptors, confirming low efficacy at $\alpha 3$-expressing receptors. We thus assessed the potential involvement of three unique amino acids we identified in TM4 (I419, I423, and V440) of the $\alpha 3$ subunit in this attenuated direct gating effect of carisoprodol. These amino acid residues were mutated to the amino acid found at the equivalent position in the $\alpha 1$ subunit, either individually or in combination. Mutation of a single amino acid $\alpha 3(\mathrm{~V} 440 \mathrm{~L})$ significantly increased the direct gating effect of carisoprodol compared with wild-type $\alpha 3$-expressing receptors (Fig. 2A). Similarly, all $\alpha 3$ mutants resulted in a gain-of-function effect, significantly increasing direct gating currents such that current amplitudes in response to $3 \mathrm{mM}$ carisoprodol were not significantly different from that obtained in wild-type $\alpha 1 \beta 2 \gamma 2$ receptors (Fig. 2B; summary values in Table 1).

Because carisoprodol also has a diminished allosteric modulatory effect in $\alpha 3 \beta 2 \gamma 2$ receptors compared with $\alpha 1 \beta 2 \gamma 2$ receptors (Kumar et al., 2015), we also assessed the extent to which these mutations might affect sensitivity to the allosteric actions of carisoprodol. Interestingly, the allosteric modulatory effects of carisoprodol were not affected by the $\alpha 3$ TM4
A

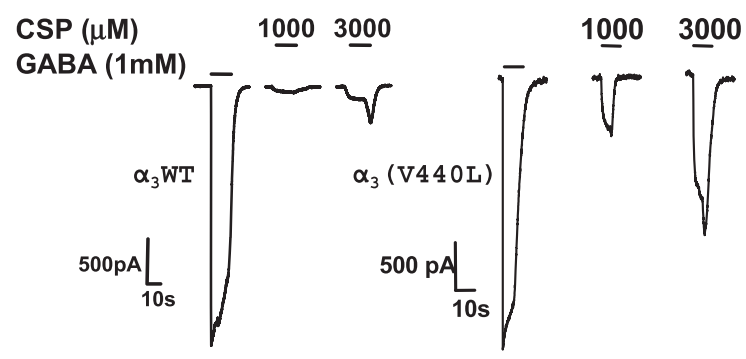

B

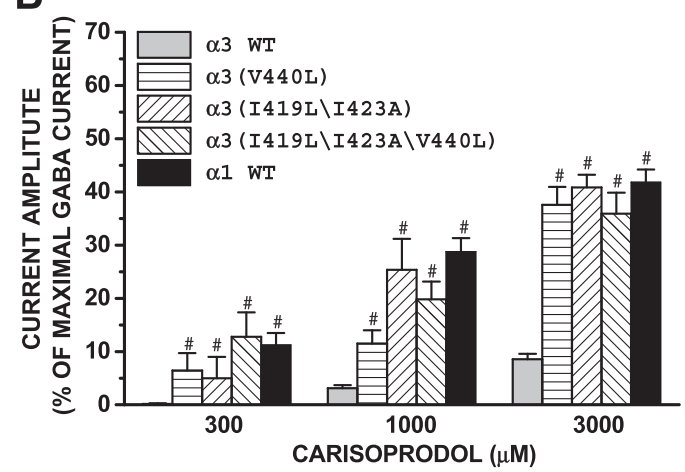

C
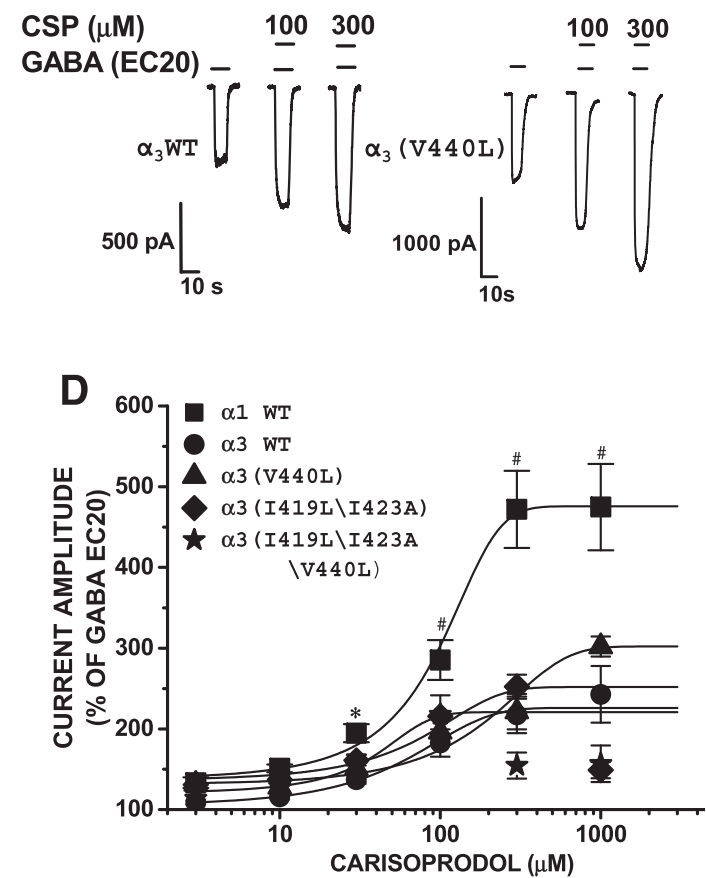

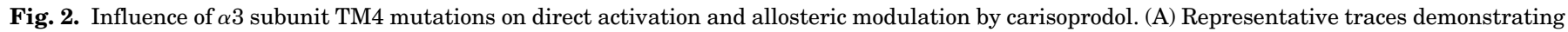

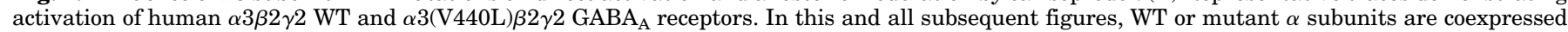

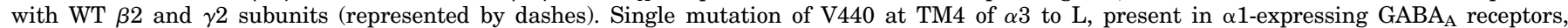

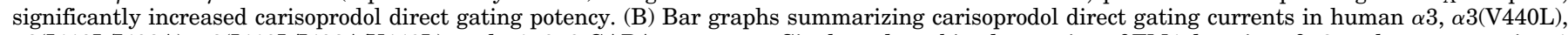

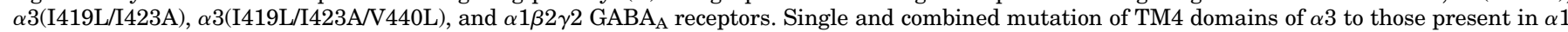

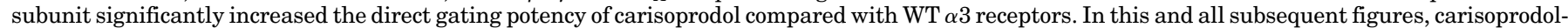

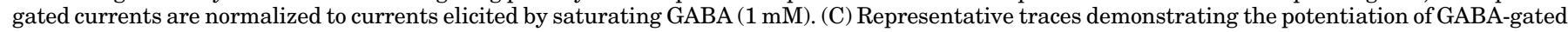

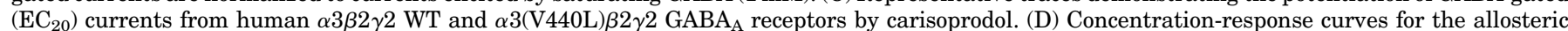

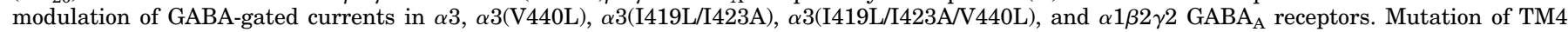

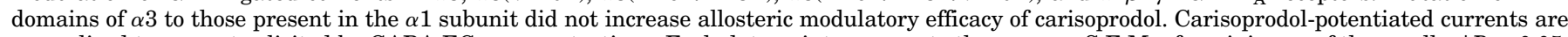

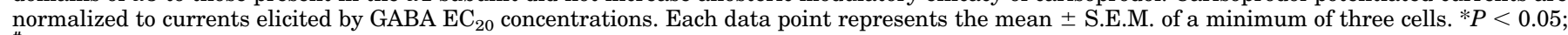
${ }^{\#} P<0.01$. CSP, carisoprodol; WT, wild type. 
mutations (Fig. 2C). Carisoprodol potentiated GABA $\mathrm{EC}_{20}$ currents in all mutated receptors; however, the magnitude of the potentiation for each mutant variant was not significantly different from that observed in $\alpha 3 \beta 2 \gamma 2$ receptors, and it fell far short of that produced in $\alpha 1 \beta 2 \gamma 2$ receptors (Fig. 2D; Table 1 ). Thus, the TM4 residues assessed here influence direct gating but not allosteric modulatory effects of carisoprodol.

Carisoprodol's less potent metabolite, meprobamate, also displays reduced direct gating effects in $\alpha 3$-expressing receptors (Kumar and Dillon, 2016) compared with all other $\alpha$ subunits. We thus evaluated the ability of these mutations to impact direct gating by meprobamate. These TM4 mutations also conferred gain-of-function effects for meprobamate direct gating, although the magnitude of effect was less than that observed with carisoprodol (Fig. 3).

A Single Mutation of $\alpha 1$ TM4 L415 Amino Acid to the Corresponding $\alpha 3$ V440 Amino Acid Decreased the Direct Gating Effect of Carisoprodol. To further assess the involvement of the identified $\alpha$ subunit TM4 residues in direct gating effects of carisoprodol, we conducted the converse set of studies. We mutated $\alpha 1$ TM 4 amino acids to the corresponding $\alpha 3$ TM4 amino acids (L394I, A398I, and L415V) in all combinations of single, double, or triple mutations and we assessed the direct gating effects of carisoprodol. $\mathrm{GABA}_{\mathrm{A}}$ receptors expressing the $\alpha 1(\mathrm{~L} 415 \mathrm{~V})$ subunit showed significantly decreased direct gating by carisoprodol compared with wild-type receptors (Fig. 4A), whereas receptors expressing the $\alpha 1$ (L394I) and $\alpha 1$ (A398I) subunits showed no significant alternation in direct gating actions of carisoprodol. Of the seven mutations we generated, each of those containing the L415V mutation caused a significant loss of the direct gating effect of carisoprodol ( $3 \mathrm{mM}$ ) compared with wild-type $\alpha 1$ receptors. Conversely, in receptors that did not incorporate the L415V mutation, carisoprodol's effects were not significantly different from the wild type (Fig. 4B; Table 2). These data indicate that the leucine residue at position 415 in the $\alpha 1$ subunit has a key role in the direct gating action of carisoprodol.

Amino Acid Residue at the $\alpha 1$ (415) Subunit Influences Carisoprodol Direct Gating Efficacy. In an attempt to gain additional insight into physicochemical determinants that influence carisoprodol direct gating capability at the $\alpha 1(415)$ position, we generated and assessed the following series of mutations: $\alpha 1$ (L415S), $\alpha 1(\mathrm{~L} 415 \mathrm{G}), \alpha 1(\mathrm{~L} 415 \mathrm{~T}) \alpha 1$ (L415Y) $\alpha 1(\mathrm{~L} 415 \mathrm{~W})$, $\alpha 1$ (L415I), $\alpha 1$ (L415C), and $\alpha 1$ (L415R). These residues provide a range of amino acid side chain properties, including volume, polarity, and hydropathy. We assessed direct gating by carisoprodol in each mutant receptor. As with the (L415V) mutation, L415S, L415G, and L415C all decreased the maximal gating efficacy of carisoprodol (to $5.5 \% \pm 1.2 \%, 9.1 \% \pm 1.6 \%$, and $18.0 \%$ $\pm 1.6 \%$ of the saturating GABA current, respectively). Potency to carisoprodol was generally unaffected, with the exception that the L415W mutant induced a 3-fold rightward shift in $\mathrm{EC}_{50}(\mathrm{Fig}$. 5 ; Table 2). The significant rightward shift in potency in receptors expressing the L415W mutation precluded accurate determination of efficacy with this mutation. The presence of T, Y, I, or $\mathrm{R}$ had no effect on either carisoprodol efficacy or potency. Correlation analysis showed positive and negative correlations of amino acid volume and polarity (Grantham, 1974), respectively, at the 415 position with carisoprodol direct gating efficacy (Fig. 6), whereas hydrophobicity tended to positively correlate with gating efficacy $(r=0.59$, critical region of -0.632 to 0.632 ). These data demonstrate that the nature of the amino acid side chain at the $\alpha 1(415)$ position is critical for the direct gating effect of carisoprodol. We also observed that an increase in $\mathrm{GABA} \mathrm{EC}_{50}$ correlated negatively with carisoprodol efficacy (Fig. 6F).

The $\alpha 1(\mathrm{L415S})$ Mutation Does Not Affect Allosteric Modulation by Carisoprodol or Direct Activation by Pentobarbital. To further assess the extent to which the $\alpha 1$ (L415) residue may be differentially involved in direct gating compared with the allosteric modulatory effects of carisoprodol, we tested whether the L415S mutation had an effect on allosteric potentiation. In $\alpha 1(\mathrm{~L} 415 \mathrm{~S}) \beta \gamma 2$ receptors, carisoprodol potentiation of $\mathrm{GABA} \mathrm{EC}_{20}$ currents did not differ
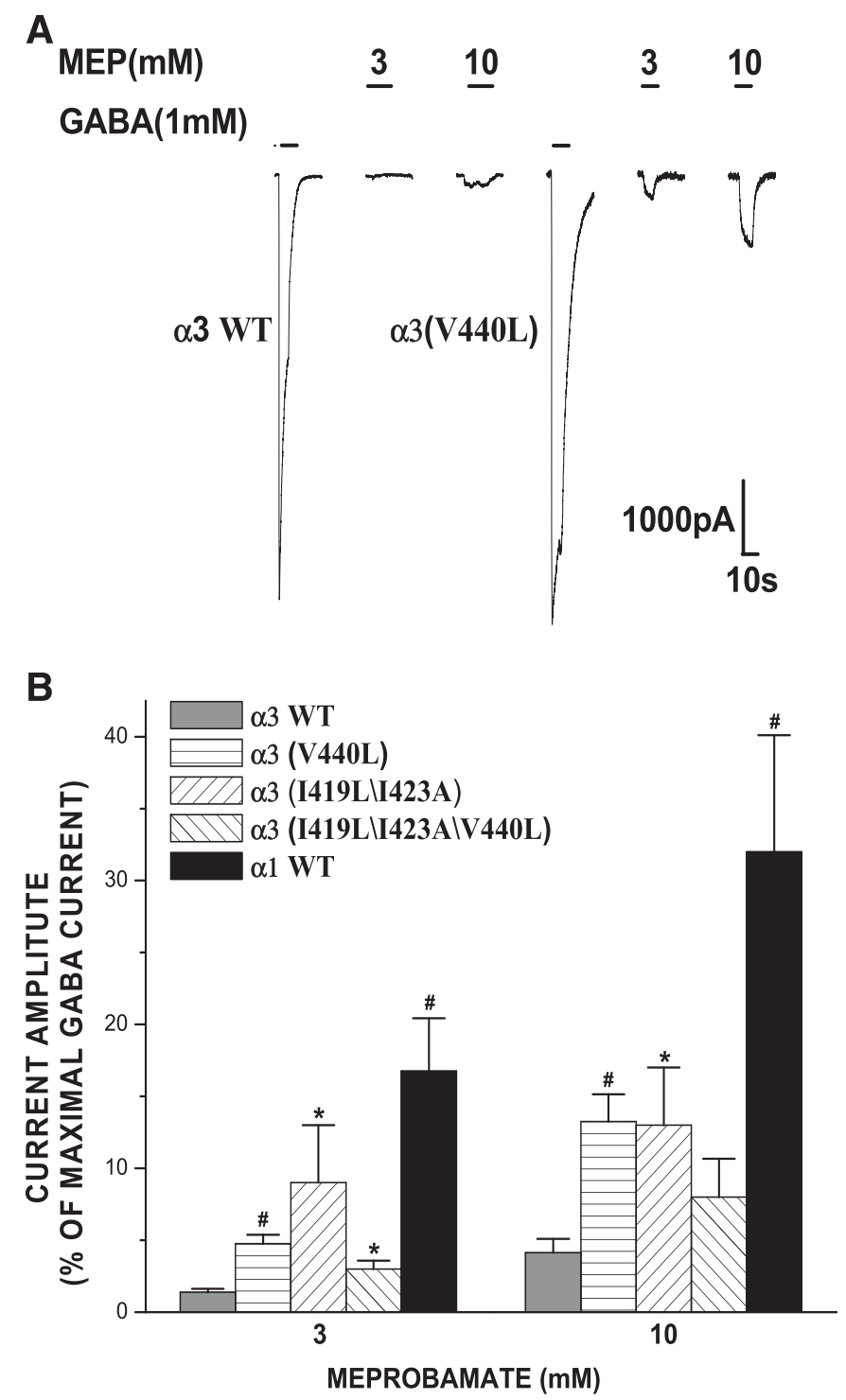

Fig. 3. Influence of $\alpha 3$-subunit TM4 mutations on direct activation of the carisoprodol metabolite meprobamate. (A) Representative traces demonstrating MEP activation of human $\alpha 3 \beta 2 \gamma 2$ WT and $\alpha 3$ (V440L) $\beta 2 \gamma 2$ $\mathrm{GABA}_{\mathrm{A}}$ receptors. (B) Bar graph summarizing meprobamate direct gating currents in $\alpha 3, \alpha 3$ (V440L), $\alpha 3$ (I419L/I423A), $\alpha 3(\mathrm{I} 419 \mathrm{~L} / \mathrm{I} 423 \mathrm{~A} / \mathrm{V} 440 \mathrm{~L})$, and $\alpha 1 \beta 2 \gamma 2 \mathrm{GABA}_{\mathrm{A}}$ receptors. Single and combined mutation of TM4 residues of the $\alpha 3$ subunit to those present in the $\alpha 1$ subunit significantly increased the direct gating potency of meprobamate compared with WT $\alpha 3$ receptors. Meprobamate-gated currents are normalized to currents elicited by saturating GABA $(1 \mathrm{mM})$. Each data point represents the mean \pm S.E.M. of a minimum of three cells. ${ }^{*} P<0.05$; ${ }^{\#} P<0.01$. CSP, carisoprodol; MEP, meprobamate; WT, wild type. 
in either maximum potentiation or potency compared with wildtype receptors, with $439.45 \% \pm 49.4 \%$ and $474.75 \% \pm 53.4 \%$ potentiation and $\mathrm{EC}_{50}$ values of $89.5 \pm 15 \mu \mathrm{M}(n=7)$ and $102.2 \pm 16 \mu \mathrm{M}(n=5)$ in $\alpha 1(\mathrm{~L} 415 \mathrm{~S}) \beta \gamma 2$ receptors compared with wild-type receptors, respectively (Fig. 7, A and B). To assess the specificity of the L415S mutation, we evaluated whether it had any effect on pentorbarbital-activated currents. Direct gating by $1 \mathrm{mM}$ pentobarbital was not significantly different in $\alpha 1$ (L415S) $\beta \gamma 2$ receptors compared with wild-type receptors, with current amplitudes of $70.2 \% \pm 4.2 \%(n=5)$ and $84.1 \% \pm$ $6.4 \%(n=7)$, respectively, compared with saturating GABA(Fig. $7, \mathrm{C}$ and D). These results are consistent with distinct sites for direct and allosteric effects of carisoprodol, and our findings demonstrate that effects of the L415S mutation are not due to nonspecific effects on the ability of direct-gating ligands to activate the channel.

An $\alpha 1$ Subunit Mutation Involved in Direct Gating by Neurosteroids Does Not Affect Direct Gating by Carisoprodol. A number of neurosteroids also have the ability to directly gate and allosterically modulate $\mathrm{GABA}_{\mathrm{A}}$ receptors. Hosie et al. (2006) demonstrated that the mutation of the native threonine in position 236 of the $\alpha 1$ subunit (T236I) to isoleucine

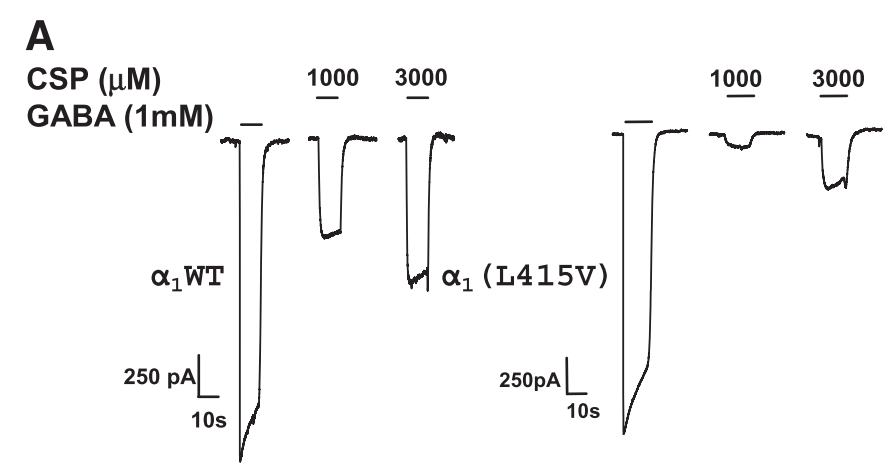

B

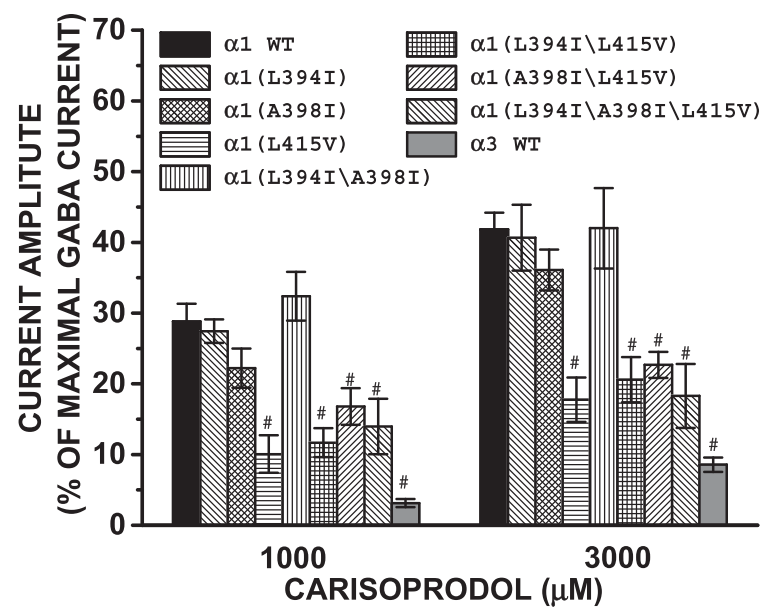

Fig. 4. Influence of $\alpha 1$ subunit TM4 mutations on direct activation by carisoprodol. (A) Representative traces demonstrating carisoprodol activation of human $\alpha 1 \beta 2 \gamma 2 \mathrm{WT}$ and $\alpha 1(\mathrm{~L} 415 \mathrm{~V}) \beta 2 \gamma 2 \mathrm{GABA}_{\mathrm{A}}$ receptors. The converse mutation to those illustrated in Fig. 2 above significantly decreased carisoprodol direct gating potency. (B) Bar graphs summarizing carisoprodol direct gating currents for human $\alpha 3, \alpha 1$ (L394I), $\alpha 1$ (A398I), $\alpha 1(\mathrm{~L} 415 \mathrm{~V}), \alpha 1(\mathrm{~L} 394 \mathrm{I} / \mathrm{A} 398 \mathrm{I})$, $\alpha 1(\mathrm{~L} 394 \mathrm{I} / \mathrm{L} 415 \mathrm{~V}), \alpha 1(\mathrm{~A} 398 \mathrm{I} / \mathrm{L} 415 \mathrm{~V}), \alpha 1(\mathrm{~L} 394 \mathrm{I} / \mathrm{A} 398 \mathrm{I} / \mathrm{L} 415 \mathrm{~V})$, and $\alpha 1 \beta 2 \gamma 2$ $\mathrm{GABA}_{\mathrm{A}}$ receptors. All $\alpha 1-\mathrm{GABA}_{\mathrm{A}}$ receptors containing the $\mathrm{L} 415 \mathrm{~V}$ mutation showed decreased carisoprodol direct gating effects compared with WT $\alpha 1 \beta 2 \gamma 2$ $\mathrm{GABA}_{\mathrm{A}}$ receptors. Each data point represents the mean \pm S.E.M. of a minimum of three cells. ${ }^{\#} P<0.01$. CSP, carisoprodol; WT, wild type. effectively abolishes direct gating by the neurosteroids tetrahydrodeoxycorticosterone (THDOC) and allopregnanolone, without affecting their allosteric potentiating effects. We thus tested
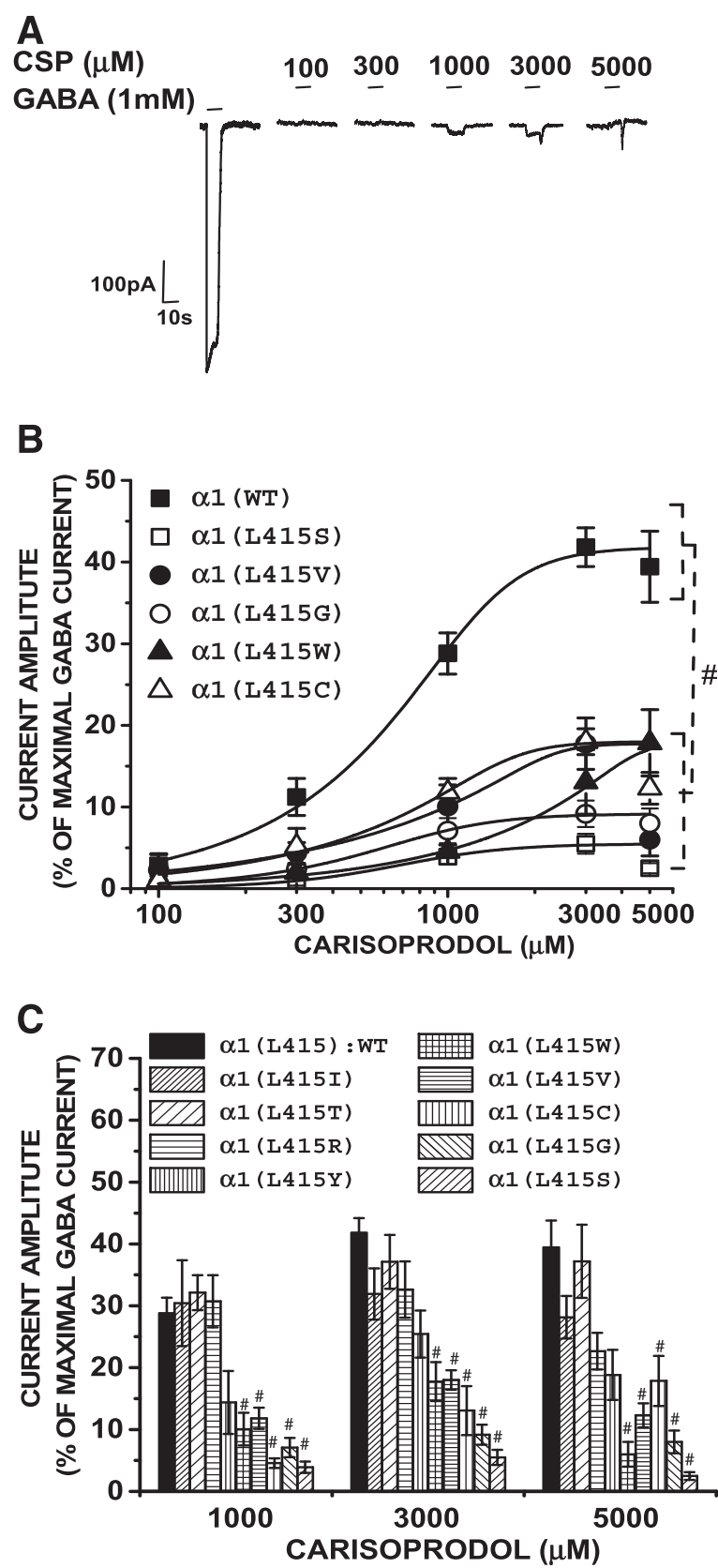

Fig. 5. Influence of $\alpha 1$-subunit TM4 L415 mutations on carisoprodol direct gating. (A) Representative traces demonstrating carisoprodol activation of human $\alpha 1$ (L415S) $\beta 2 \gamma 2 \mathrm{GABA}_{\mathrm{A}}$ receptors. Nominal direct gating by carisoprodol was present in this mutation, at concentrations up to $5 \mathrm{mM}$. (B) Concentration-response curves for the direct gating effect of carisoprodol from human $\alpha 1$ (L415S), $\alpha 1$ (L415V), $\alpha 1$ (L415G), $\alpha 1$ (L415W), $\alpha 1$ (L415C), and $\alpha 1 \beta 2 \gamma 2 \mathrm{GABA}_{\mathrm{A}}$ receptors. These five mutations all decreased carisoprodol efficacy significantly without affecting carisoprodol $\mathrm{EC}_{50}$, except for the $\alpha 1$ (L415W) mutant, which increased $\mathrm{EC}_{50}$ an estimated 3-fold relative to WT receptors. (C) Bar graphs summarizing carisoprodol direct gating currents for human $\alpha 1$ WT, $\alpha 1$ (L415I), $\alpha 1$ (L415T), $\alpha 1$ (L415R), $\alpha 1$ (L415Y), $\alpha 1(\mathrm{~L} 415 \mathrm{~W}), \alpha 1(\mathrm{~L} 415 \mathrm{~V}), \alpha 1(\mathrm{~L} 415 \mathrm{C}), \alpha 1(\mathrm{~L} 415 \mathrm{G})$, and $\alpha 1(\mathrm{~L} 415 \mathrm{~S}) \beta 2 \gamma 2 \mathrm{GABA}_{\mathrm{A}}$ receptors. The carisoprodol-gated current reached saturation at $5 \mathrm{mM}$. Receptors containing $\alpha 1$ (L415T/R/Y/I) mutations did not affect carisoprodol direct gating efficacy; thus, carisoprodol $\mathrm{EC}_{50}$ values were not calculated. Each data point represents the mean \pm S.E.M of a minimum of three cells. ${ }^{\#} P<0.01$. CSP, carisoprodol; WT, wild type. 
whether the $\alpha 1$ (T236I) mutation affected carisoprodol direct gating actions. This mutation did not produce any change in the ability of carisoprodol to directly activate wild-type receptors (Fig. 8).

\section{Discussion}

In a recent report (Kumar et al., 2015), we found that direct gating effects of the skeletal muscle relaxant carisoprodol were reduced in $\alpha 3 \beta \gamma 2 \mathrm{GABA}_{\mathrm{A}}$ receptors compared with those expressing any other $\alpha$ subunit variant ( $\alpha 1-2, \alpha 4-6)$. Here, we identified $\alpha$-subunit TM4 residues, particularly $\alpha 1415$ (equivalent to $\alpha 3440$ ), that are critical for the direct gating, but not allosteric modulatory, effects of carisoprodol. Mutation of the native $\alpha 3440 \mathrm{~V}$ residue to the $\mathrm{L}$ residue found in the $\alpha 1$ subunit (V440L) resulted in a significant enhancement of carisoprodolgated current; the converse mutation $[\alpha 1(\mathrm{~L} 415 \mathrm{~V})]$ had the opposite effect. Direct gating efficacy of carisoprodol's primary metabolite, meprobamate, was also influenced by the L415 mutations. Subsequent evaluation of a series of mutations resulted in the following rank-order effect on carisoprodol gating efficacy $(\mathrm{L}=\mathrm{I}=\mathrm{T}=\mathrm{R}>\mathrm{Y}>\mathrm{W}=\mathrm{C}=\mathrm{V}>\mathrm{G}>\mathrm{S}$ ), and correlation analysis demonstrated that both amino acid volume and polarity are important determinants of this position's effect on carisoprodol direct gating. The presence of a hydrophobic residue tended to correlate with enhanced carisoprodol gating, although this effect did not reach statistical significance. Interestingly, except for tryptophan (which caused a 3-fold increase in carisoprodol direct gating $\mathrm{EC}_{50}$ ), none of the introduced mutants affected the potency of carisoprodol's direct gating effect; the action was nearly exclusively an effect on efficacy.

Considering that we showed previously that carisoprodol inhibits the $\mathrm{GAB}_{\mathrm{A}} \mathrm{A}$ receptor-associated channel at high concentration (Gonzalez et al., 2009b; Kumar et al., 2015; note also the rebound current in Fig. $2 \mathrm{~B}$ after removal of carisoprodol), one might also consider the possibility that the effects of the mutations studied could be due to shifting carisoprodol's ability to inhibit the channel. For example, the $\alpha 3$ V440L mutation possibly attenuates carisoprodol-mediated inhibition instead of enhancing carisoprodol-mediated direct gating. Although we cannot definitively rule out this possibility, we consider it unlikely. We previously reported in abstract form (Kumar and Dillon, 2014) that the ability of carisoprodol to block $\alpha 1 \beta 2 \gamma 2$ or homomeric $\beta 3 \mathrm{GABA}_{\mathrm{A}}$ receptors is greatly attenuated or eliminated, respectively, when the $6^{\prime}$ tyrosine residue in the second TM domain is mutated to phenylalanine. The TM2 domain thus seems to be involved in carisoprodol-mediated channel inhibition, whereas the TM4 residue targeted here is important for direct gating by carisoprodol.

TM4 residues of the $\alpha 1$ subunit are shown to be involved in allosteric modulatory effects of other $\mathrm{GABA}_{\mathrm{A}}$ receptor ligands, such as neurosteroids and anesthetics (Jenkins et al., 2002; Hosie et al., 2006). Homology modeling has shown that N407 and Y410 donate a hydrogen bond to the ketone group of THDOC and contribute to the binding pocket of neurosteroids. Substitution of polar residues to hydrophobic amino acids at N407A and Y410F reduced THDOC potency significantly (Hosie et al., 2006). Indeed, L415 has been implicated in effects
A

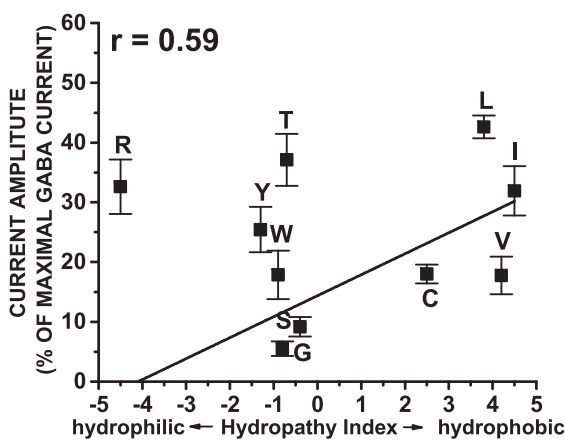

D

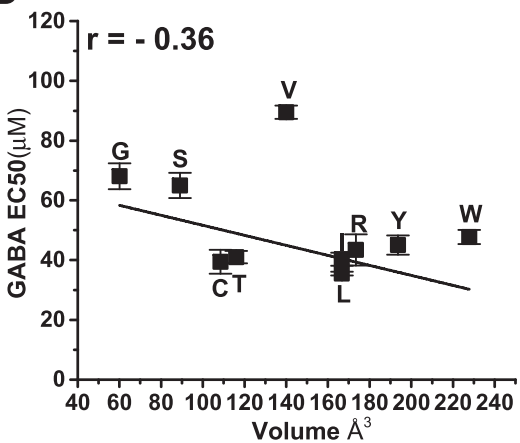

B

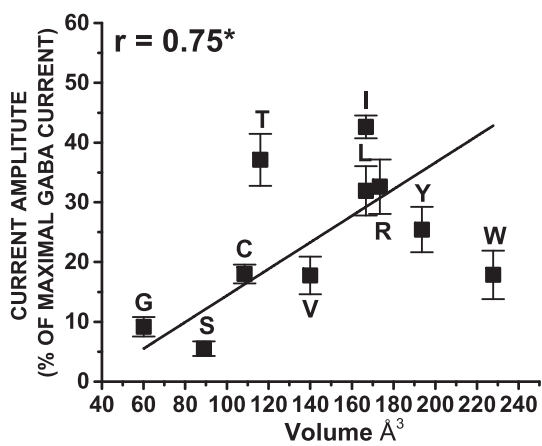

E

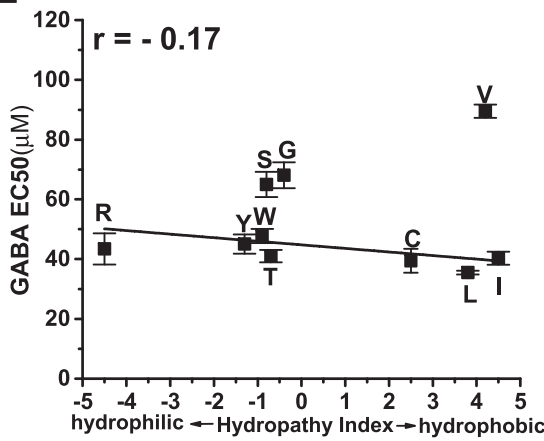

C

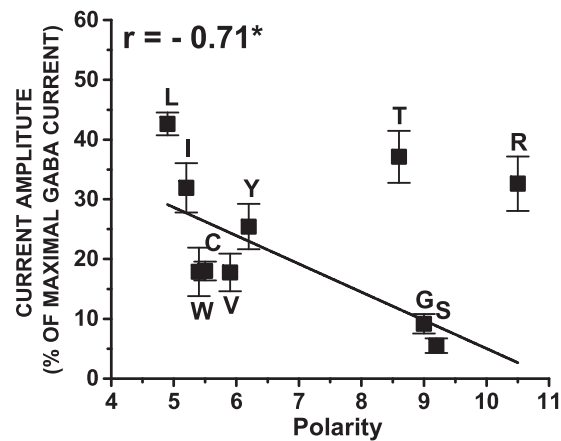

$F$

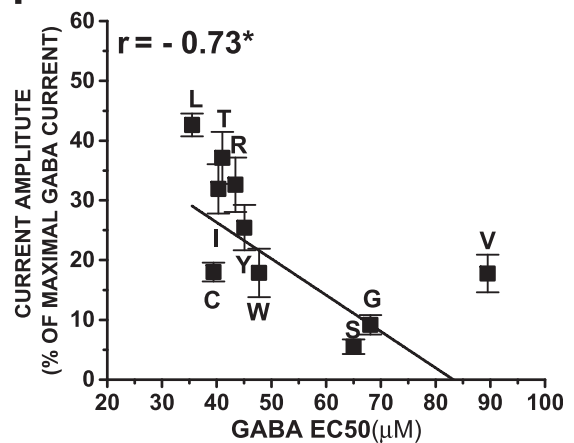

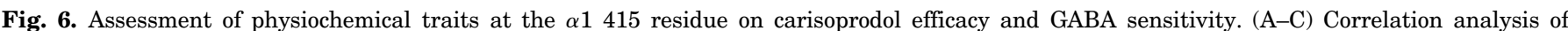

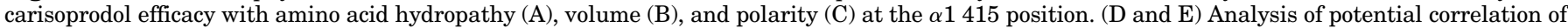

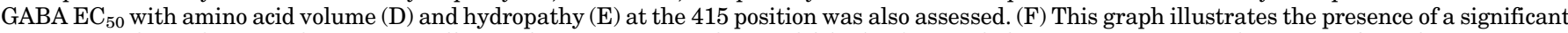

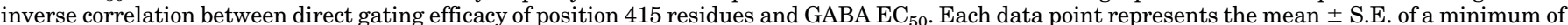
three cells. CSP, carisoprodol; WT, wild type. 
A
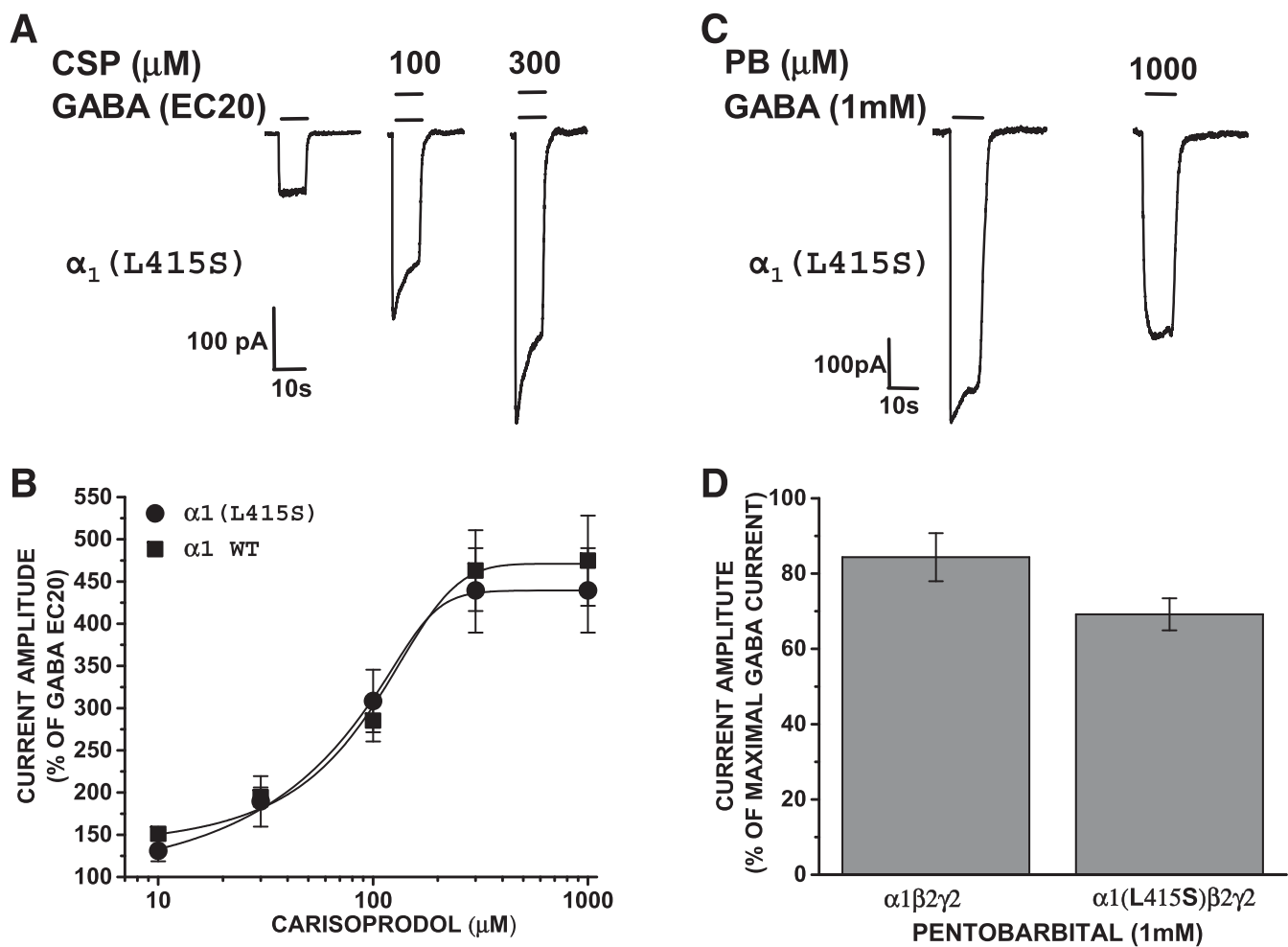

Fig. 7. Influence of the $\alpha 1$ subunit TM4 L415S mutation on allosteric modulation by carisoprodol and pentobarbital direct activation. (A) Representative traces demonstrating carisoprodol potentiation of GABA-gated $\left(\mathrm{EC}_{20}\right.$ ) currents in $\alpha 1(\mathrm{~L} 415 \mathrm{~S}) \beta 2 \gamma 2 \mathrm{GABA}_{\mathrm{A}}$ receptors. (B) Concentrationresponse curves for the allosteric modulation of GABA-gated currents in WT $\alpha 1 \beta 2 \gamma 2$ and $\alpha 1(\mathrm{~L} 415 \mathrm{~S}) \beta 2 \gamma 2 \mathrm{GABA}_{\mathrm{A}}$ receptors. Mutation of leucine to serine at the $\alpha 1(415)$ position did not affect allosteric modulation by carisoprodol. Carisoprodol-potentiated currents are normalized to currents elicited by

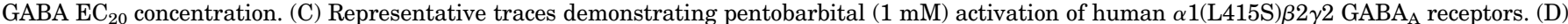
Bar graphs summarizing pentobarbital direct gating currents in WT $\alpha 1 \beta 2 \gamma 2$ and $\alpha 1(\mathrm{~L} 415 \mathrm{~S}) \beta 2 \gamma 2 \mathrm{GABA}_{\mathrm{A}}$ receptors. In contrast with effects on carisoprodol direct gating, this mutation did not affect direct gating by pentobarbital. Pentobarbital-gated currents are normalized to the currents elicited by saturating concentration of GABA $(1 \mathrm{mM})$. Each data point represents the mean \pm S.E. of a minimum of three cells. CSP, carisoprodol; PB, pentobarbital; WT, wild type.

mediated by anesthetic agents. In a tryptophan scanning study of TM4, Jenkins et al. (2002) found that introduction of tryptophan at position 415 (L415W) of the $\alpha 1$ subunit produced a significant decrease in the ability of the anesthetics halothane and chloroform to potentiate GABA-gated currents. It is possible that TM domains form an important allosteric modulatory site on $\mathrm{GABA}_{\mathrm{A}}$ receptors. However, our results would seem to rule out the potential involvement of the TM4 domain 415 position for allosteric effects of carisoprodol, because the (L415S) mutation had no effect on the ability of carisoprodol to allosterically enhance GABA-gated current. These results are most consistent with the conclusion that distinct sites exist for the allosteric modulatory and direct gating effects of carisoprodol.

Previous molecular and behavior studies of carisoprodol have demonstrated characteristics of barbiturate-like effects. Both ligands directly gate, allosterically modulate, and inhibit the receptor (at high concentrations). More notably, in drug discrimination studies, the barbiturate pentobarbital substituted for the discriminative stimulus effects of carisoprodol in carisoprodoltrained rats. In addition, the barbiturate antagonist bemegride blocked the locomotor-depressive effect of carisoprodol in mice and also antagonized carisoprodol-gated currents in HEK293 cells expressing $\mathrm{GABA}_{\mathrm{A}}$ receptors (Gonzalez et al., 2009b). These findings suggested that the behavioral and molecular action of carisoprodol may be mediated by a barbiturate-like mechanism of action on $\mathrm{GABA}_{\mathrm{A}}$ receptors. However, in this study, the $\alpha 1(\mathrm{~L} 415 \mathrm{~S})$ mutation did not affect the ability of pentobarbital to directly gate $\mathrm{GABA}_{\mathrm{A}}$ receptors. In addition, a $\rho$ receptor mutation that confers sensitivity to barbiturates (the wild type is insensitive to barbiturates) did not confer sensitivity to carisoprodol (Gonzalez et al., 2009b). Thus, although previous studies have shown barbiturate-like action of carisoprodol, collectively the data support distinct binding sites and/or functional domains for carisoprodol versus barbiturate direct gating effects in $\mathrm{GABA}_{\mathrm{A}}$ receptors. We also found that the $\alpha 1 \mathrm{~T} 236 \mathrm{I}$ mutation, shown previously to abolish direct gating by neurosteroids (Hosie et al., 2006), did not affect carisoprodol-mediated activation. Thus, although the $\alpha 1$ (T236) position is critical for direct gating by neurosteroids, it does not have a significant role in direct gating in response to carisoprodol.

The primary metabolite of carisoprodol, meprobamate, also directly gates $\mathrm{GABA}_{\mathrm{A}}$ receptors, with a potency severalfold lower than that of carisoprodol. The sole structural difference between the two ligands is the presence of an isopropyl group present on one of the two carbamyl nitrogens in carisoprodol; this functional group thus dictates the differences in potency between the two ligands. Although valine and leucine are similarly hydrophobic and both are of low polarity, one may speculate that the larger volume of leucine may make it more accessible for hydrophobic interaction with the isopropyl group present on the carbamyl nitrogen in carisoprodol. Although the $\alpha 3(\mathrm{~V} 440 \mathrm{~L})$ mutation did result in enhanced gating of meprobamate (which lacks the isopropyl substituent), the fact that 


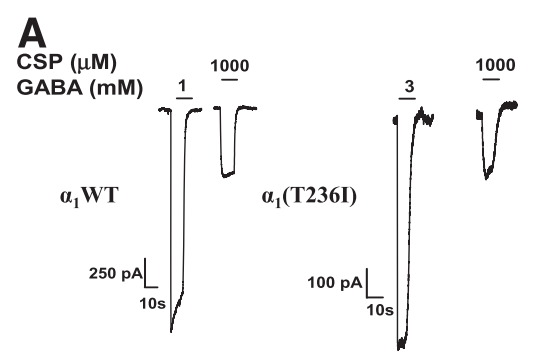

B

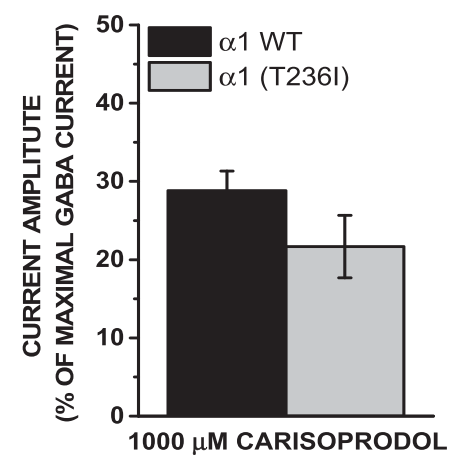

Fig. 8. Mutation of threonine at the 236 position of the $\alpha 1$ subunit to isoleucine does not affect the direct gating potency of carisoprodol at $\alpha 1 \beta 2 \gamma 2$ receptors. (A) Representative traces demonstrating that carisoprodol activates human $\alpha 1 \beta 2 \gamma 2 \mathrm{WT}$ and $\alpha 1$ (T236I) $\beta 2 \gamma 2 \mathrm{GABA}_{\mathrm{A}}$ receptors. (B) Bar graph summarizing $1 \mathrm{mM}$ carisoprodol direct gating currents for human $\alpha 1 \beta 2 \gamma 2$ WT $(28.8 \pm 2.5, n=6)$ and $\alpha 1(\mathrm{~T} 236 \mathrm{I}) \beta 2 \gamma 2 \mathrm{GABA}_{\mathrm{A}}$ receptors $(21.7 \pm 4.0, n=3)$. Mutation of $\alpha 1$ (T236I) did not show significant alteration in direct gating potency of carisoprodol compared with WT $\alpha 1 \beta 2 \gamma 2$ $\mathrm{GABA}_{\mathrm{A}}$ receptors. Carisoprodol-gated currents are normalized to currents elicited by saturated GABA concentration. Human $\alpha 1 \beta 2 \gamma 2$ WT data reproduced from Fig. 3. CSP, carisoprodol; WT, wild type.

the magnitude of the effect was considerably smaller than that observed with carisoprodol would be consistent with this possibility. Alternatively, the isopropyl group may not directly interact with the $\alpha 1415$ leucine residue but may instead influence its interaction with other regions of the receptor. Molecular modeling studies will be required to address these possibilities.

It is known that addictive drugs hijack the reward system by increasing dopamine levels in the mesolimbic system (Lüscher and Ungless, 2006). For example, benzodiazepines meditate their addictive actions by increasing dopamine release in the nucleus accumbens through activation of $\alpha 1$-containing $\mathrm{GABA}_{\mathrm{A}}$ receptors on GABAergic interneurons in the ventral tegmental area (Heikkinen et al., 2009; Tan et al., 2010; Rudolph and Knoflach, 2011). Moreover, behavior studies in transgenic mice expressing mutant $\alpha$-subunit isoforms have been instrumental in demonstrating distinct physiologic effects of benzodiazepines associate with particular subunits. For instance, $\alpha 1$-expressing receptors are involved in sedative effects and abuse potential, $\alpha 2$-expressing receptors contribute to their anxiolytic effects, and $\alpha 2-, \alpha 3$-, and $\alpha 5$-expressing receptors are involved in the myorelaxant actions of benzodiazepines (Rudolph et al., 1999; Löw et al., 2000; Crestani et al., 2001; van Rijnsoever et al., 2004; Licata and Rowlett, 2008). In parallel with what is understood with regard to benzodiazepines, the robust effects of carisoprodol on $\alpha 1$-expressing receptors (this study; also see Kumar and Dillon, 2015) likely underlie its well documented potential for abuse.

In summary, we have identified a TM4 residue of the GABA receptor that is critically involved in the direct gating actions of the skeletal muscle relaxant carisoprodol, and we also identified physicochemical traits that are important for this effect. Mutation of this residue did not impact the allosteric modulatory effects of carisoprodol, and it also had no effect on the ability of the barbiturate pentobarbital to directly gate the receptor. These results are consistent with our contention that carisoprodol mediates these two actions through distinct sites on the $\mathrm{GABA}_{\mathrm{A}}$ receptor. In addition, as noted recently (Kumar and Dillon, 2016), an array of meprobamate-related dicarbamate molecules were generated years ago, when both meprobamate and carisoprodol were being widely prescribed (Ludwig et al., 1969). Many of these molecules showed promise as muscle relaxants in preclinical studies; however, to our knowledge, none advanced to market. The potential reasons are many, including the fact that meprobamate was scheduled as a controlled substance soon thereafter. Given our current understanding of $\mathrm{GABA}_{\mathrm{A}}$ receptor molecular pharmacology associated with therapeutic and adverse effects, it is feasible that reassessment of these molecules and potential derivatives would yield an efficacious muscle relaxant with considerably reduced abuse potential.

\section{Authorship Contributions}

Participated in research design: M.o. Kumar, M.i. Kumar, Dillon. Conducted experiments: M.o. Kumar, M.i. Kumar, Freund.

Performed data analysis: M.o. Kumar, M.i. Kumar, Freund, Dillon. Wrote or contributed to the writing of the manuscript: M.o. Kumar, M.i. Kumar, Dillon.

\section{References}

Bali M and Akabas MH (2004) Defining the propofol binding site location on the GABAA receptor. Mol Pharmacol 65:68-76.

Barnard EA, Skolnick P, Olsen RW, Mohler H, Sieghart W, Biggio G, Braestrup C, Bateson AN, and Langer SZ (1998) International Union of Pharmacology. XV Subtypes of gamma-aminobutyric acidA receptors: classification on the basis of subunit structure and receptor function. Pharmacol Rev 50:291-313.

Bergmann R, Kongsbak K, Sørensen PL, Sander T, and Balle T (2013) A unified model of the GABA(A) receptor comprising agonist and benzodiazepine binding sites. PLoS One 8:e52323.

Bramness JG, Skurtveit S, and Mørland J (2004) Impairment due to intake of carisoprodol. Drug Alcohol Depend 74:311-318.

Cockcroft V, Ortells M, and Lunt G (1995) Ligands, receptor models, and evolution. Ann N Y Acad Sci 757:40-47.

Corringer PJ, Poitevin F, Prevost MS, Sauguet L, Delarue M, and Changeux JP (2012) Structure and pharmacology of pentameric receptor channels: from bacteria to brain. Structure 20:941-956.

Crestani F, Löw K, Keist R, Mandelli M, Möhler H, and Rudolph U (2001) Molecular targets for the myorelaxant action of diazepam. Mol Pharmacol 59:442-445.

Fass JA (2010) Carisoprodol legal status and patterns of abuse. Ann Pharmacother 44:1962-1967.

Gatch MB, Nguyen JD, Carbonaro T, and Forster MJ (2012) Carisoprodol tolerance and precipitated withdrawal. Drug Alcohol Depend 123:29-34.

Gonzalez LA, Gatch MB, Forster MJ, and Dillon GH (2009a) Abuse potential of Soma: the GABA(A) receptor as a target. Mol Cell Pharmacol 1:180-186.

Gonzalez LA, Gatch MB, Taylor CM, Bell-Horner CL, Forster MJ, and Dillon GH (2009b) Carisoprodol-mediated modulation of GABAA receptors: in vitro and in vivo studies. J Pharmacol Exp Ther 329:827-837.

Grantham R (1974) Amino acid difference formula to help explain protein evolution. Science 185:862-864

Heikkinen AE, Möykkynen TP, and Korpi ER (2009) Long-lasting modulation of glutamatergic transmission in VTA dopamine neurons after a single dose of benzodiazepine agonists. Neuropsychopharmacology 34:290-298.

Hosie AM, Wilkins ME, da Silva HM, and Smart TG (2006) Endogenous neurosteroids regulate GABAA receptors through two discrete transmembrane sites. Nature 444:486-489.

Jenkins A, Andreasen A, Trudell JR, and Harrison NL (2002) Tryptophan scanning mutagenesis in TM4 of the GABA(A) receptor alpha1 subunit: implications for modulation by inhaled anesthetics and ion channel structure. Neuropharmacology 43:669-678.

Kumar M and Dillon GH (2014) Distinct amino acid domains confer direct gating, allosteric modulation and blocking properties of carisoprodol on GABA(A) receptors (Abstract). Program 124.16/B31. 2014 Neuroscience Meeting Planner. Washington, DC: Society for Neuroscience.

Kumar M and Dillon GH (2015) Carisoprodol: update on abuse potential and mechanism of action. Mol Cell Pharmacol 7:1-10.

Kumar M and Dillon GH (2016) Assessment of direct gating and allosteric modulatory effects of meprobamate in recombinant GABA(A) receptors. Eur J Pharmacol 775:149-158. 
Kumar M, González LA, and Dillon GH (2015) Assessment of subunit-dependent direct gating and allosteric modulatory effects of carisoprodol at GABA(A) receptors. Neuropharmacology 97:414-425.

Licata SC and Rowlett JK (2008) Abuse and dependence liability of benzodiazepinetype drugs: GABA(A) receptor modulation and beyond. Pharmacol Biochem Behav 90:74-89.

Löw K, Crestani F, Keist R, Benke D, Brünig I, Benson JA, Fritschy JM, Rülicke T, Bluethmann H, Möhler H, et al. (2000) Molecular and neuronal substrate for the selective attenuation of anxiety. Science 290:131-134.

Ludwig BJ, Powell LS, and Berger FM (1969) Carbamate derivatives related to meprobamate. J Med Chem 12:462-472.

Luo X, Pietrobon R, Curtis LH, and Hey LA (2004) Prescription of nonsteroidal antiinflammatory drugs and muscle relaxants for back pain in the United States. Spine 29:E531-E537.

Lüscher C and Ungless MA (2006) The mechanistic classification of addictive drugs. PLoS Med 3:e437.

Miyazawa A, Fujiyoshi Y, and Unwin N (2003) Structure and gating mechanism of the acetylcholine receptor pore. Nature 423:949-955.

Newell JG and Czajkowski C (2003) The GABAA receptor alpha 1 subunit Pro174Asp191 segment is involved in GABA binding and channel gating. $J$ Biol Chem 278:13166-13172.

Olsen RW and Sieghart W (2008) International Union of Pharmacology. LXX. Subtypes of gamma-aminobutyric acid(A) receptors: classification on the basis of subunit composition, pharmacology, and function. Update. Pharmacol Rev 60: $243-260$.

Reeves RR and Burke RS (2010) Carisoprodol: abuse potential and withdrawal syndrome. Curr Drug Abuse Rev 3:33-38.

Reeves RR, Burke RS, and Kose S (2012) Carisoprodol: update on abuse potential and legal status. South Med J 105:619-623.

Rudolph U, Crestani F, Benke D, Brünig I, Benson JA, Fritschy JM, Martin JR, Bluethmann H, and Möhler H (1999) Benzodiazepine actions mediated by specific gamma-aminobutyric acid(A) receptor subtypes. Nature 401:796-800.

Rudolph U and Knoflach F (2011) Beyond classical benzodiazepines: novel therapeutic potential of GABAA receptor subtypes. Nat Rev Drug Discov 10:685-697.

Siegwart R, Jurd R, and Rudolph U (2002) Molecular determinants for the action of general anesthetics at recombinant alpha(2)beta(3)gamma(2)gamma-aminobutyric acid(A) receptors. $J$ Neurochem 80:140-148.
Sigel E and Steinmann ME (2012) Structure, function, and modulation of GABA(A) receptors. J Biol Chem 287:40224-40231.

Stewart DS, Hotta M, Desai R, and Forman SA (2013) State-dependent etomidate occupancy of its allosteric agonist sites measured in a cysteine-substituted GABAA receptor. Mol Pharmacol 83:1200-1208.

Tan KR, Brown M, Labouèbe G, Yvon C, Creton C, Fritschy JM, Rudolph U, and Lüscher C (2010) Neural bases for addictive properties of benzodiazepines. Nature 463:769-774.

Toth PP and Urtis J (2004) Commonly used muscle relaxant therapies for acute low back pain: a review of carisoprodol, cyclobenzaprine hydrochloride, and metaxalone. Clin Ther 26:1355-1367.

van Rijnsoever C, Täuber M, Choulli MK, Keist R, Rudolph U, Mohler H, Fritschy JM, and Crestani F (2004) Requirement of alpha5-GABAA receptors for the development of tolerance to the sedative action of diazepam in mice. $J$ Neurosci 24 : $6785-6790$

$\mathrm{Xu}$ M and Akabas MH (1996) Identification of channel-lining residues in the M2 membrane-spanning segment of the GABA(A) receptor alpha1 subunit. J Gen Physiol 107:195-205.

Zacny JP and Gutierrez S (2011) Subjective, psychomotor, and physiological effects of oxycodone alone and in combination with ethanol in healthy volunteers. Psychopharmacology (Berl) 218:471-481.

Zacny JP, Paice JA, and Coalson DW (2011) Characterizing the subjective and psychomotor effects of carisoprodol in healthy volunteers. Pharmacol Biochem Behav 100:138-143.

Zeller A, Arras M, Jurd R, and Rudolph U (2007a) Identification of a molecular target mediating the general anesthetic actions of pentobarbital. Mol Pharmacol $\mathbf{7 1}$ : 852-859.

Zeller A, Arras M, Jurd R, and Rudolph U (2007b) Mapping the contribution of beta3containing GABAA receptors to volatile and intravenous general anesthetic actions. BMC Pharmacol 7:2

Address correspondence to: Dr. Glenn H. Dillon, Center for Neuroscience Discovery, Institute for Healthy Aging, LIB 313, 3500 Camp Bowie Blvd., University of North Texas Health Science Center, Fort Worth, TX 76107. E-mail: glenn.dillon@unthsc.edu 